\title{
Work-Life Balance Imperatives for Modern Work Organization: A Theoretical Perspective
}

\author{
AKINYELE, Samuel Taiwo (PhD) \\ Dept. of Entrepreneurial Studies, College of Management Sciences, \\ Federal University of Agriculture, Abeokuta, Nigeria \\ akinyelest@funaab.edu.ng \\ PETERS, Miebaka Catherine \\ Dept.of Business Management, School of Business, \\ Covenant University, Ota, pmb 1023, Ogun State, Nigeria

\section{AKINYELE, Feyisayo Esther} \\ School of Postgraduate, Crawford University, Igbesa, Nigeria \\ feyisayosam@yahoo.com
}

\begin{abstract}
Work life balance is considered to be a crucial factor in relation to employee performance. The objective of this study is to review theoretical literature on work life balance as it affect modern work organization. The research work sought to explore extensively whether these is relationship between work flexibility and quality of output, employer/employee relationship and increased productivity, working environment and the rate of turnover and lastly job security and employee retention. Therefore the study indicated that work flexibility, employer/employee relationship, working environment and job security have a positive effect on improved quality of output, increased productivity, rate of turnover among employees, employee retention. The findings showed that: employees react negatively when they experience work life imbalance and that management should adopt work life balance initiatives to improve employee performance. From the research findings, it has been concluded that work life balance is of significant essence to modern work organizations.
\end{abstract}

Keywords: Employee performance, Work-life balance, Employee retention, Job security, Organization, Working environment.

\section{INTRODUCTION}

In modern time, there has been an increase in the thought of the burdens that work has on family as well as life of employees. This has prompted exploration bordering on wok-life (WLB). In an environment where there is high level of competitive weights stemming largely from labors to bring excellence service, the weightiness of this on workers are massive. This is so because the question of conflict or line between people's private lives and occupational stress is critical to understanding how organizational can leverage on their performance and productivity levels as well as motivating staff for employee commitment (Deery, 2008; Cannon, 1998; Aluko, 2009). Till recently, the subject of WLB was regarded mostly as a Western idea; but this has drastically changed as African (Nigerian) women have taken up paid employment in the contemporary era in order to be part of provision of family needs. Nevertheless, this has also come with a huge price as families, organizations and social lives are impacted in the process.

In its list of the 100 best companies to work for, Fortune magazine identifies organizations that make an effort to assist employees in managing the duties of work and family (Muse et al., 2008). Thus, organizational efforts for ensuring employees' work-life balance are needed and valued more than ever.

Many researchers have generally agreed on the important role of work-life balance as it is related with an individual's psychological well-being and overall sense of harmony in life, which is an indicator of balance between the workplace role and the role in family (Clark, 2000; Marks \&MacDermid, 1996). 
Recent research shows that both employees and organizations benefit from successfully balanced work and family life (e.g., Greenhaus\& Powell, 2006; Hammer et al., 2005). Work-life balance enhances their well-being and family satisfaction (Grzywacz, 2000). In work domains, the absence of work-life balance causes poor performance and more absenteeism of employees (Frone et al., 1997), but balanced work and family life is associated with increased job satisfaction and organizational commitment (Cegarra-Leiva et al., 2012; Wayne et al., 2004). In other words, employees' work-life balance experiences deepen their role-related engagement, which is related to organizational performance improvement (Carlson et al., 2006).

\section{Statement of Research Problems}

The pressure of work, for those in work has been escalating over the latest decades. Factors such as the advances in information technology, and information load, the need for speedy response, the importance attached to the quality of customer service and its implication for constant availability and the pace of change all demand our time and can be sources of pressure. In Nigeria today, enough emphasis is not placed on employees balance between work and family and the effect it has on the employee's stability which in turn affect the productivity which also affects the turnover in the organization as there in no balance. Changing demographics are behind the move to embrace worklife programs. The decline of the traditional family, and increase in dual-career couples, and a rise in the number of single parents mean that employees are juggling more responsibilities outside work.

Typically, studies have focused on employed men and women who are married or living with a partner or those with children. Omitted from research are single-earner mothers and fathers, single and childless employees with extensive responsibility for eldercare, blended families with children from both partners' prior marriages, families with shared custody of children, and grandparents raising their grandchildren. Work-life balance in the workplace has become a more important issue as lack of it tends to exhibit negative results such as high turnover, decrease in work engagement, low quality of output, low productivity, and lack of job satisfaction.

Research indicates that employee motivation and productivity is low when work/life initiatives are absent, company commitment to work/life initiatives is closely aligned with employee motivation and productivity. A study focusing on work, well-being and stress illustrates this link, finding that " $45 \%$ of men and 50\% of women would turn down a promotion if the new position would leave them with less time for their personal or family life." Also, work-balance issues are factors that affect employee retention with the company. The cost of employee turnover and accompanying loss of valuable company knowledge can be significant. Work/life programs offer a solution to retention anguish. A prime example is IBM's 1992 workforce survey that documented "the highest performers are the most likely to consider their ability to balance work and personal responsibilities in a decision to stay with the company.

Work-life balance has started giving organizations and homes concern due to its importance; it has effects on various sectors of both the employees which eventually affect the organizations. Negligence of work-life balance of employees have cost organizations, hence the need to prioritize it. Some people have debunked the notion that work-life balance can be attained such as Alain De Botton (2001) who said "There is no such thing as work-life balance. Everything worth fighting for unbalances your life." While some have supported the notion like: Heather (2011) "You will never feel truly satisfied by work until you are satisfied by life."

Nowadays most managers do not have the knowledge of the benefits of effective work-life balance on employee performance and productivity; managers fail to realize that good management and higher productivity come at the expense of work-life balance. Contending and multi-confronted requests between work and home obligations have expected expanded pertinence for employees as of late, due in vast part to demographic and working environment changes, for example, a more noteworthy quantities of ladies in the workforce (double profession couples), change in family structures (an ascent in the quantity of single folks), a developing hesitance to acknowledge the more drawn out hours culture, the ascent of the 24 every 7 general public, and innovative advancement.

\section{LiteratURE REVIEW}

Work-life balance: "Work-life integration or balance is defined as a process for reconciliation of work, family and individual self-demands and time. (Grady \& McCarthy (2008). "Work-life balance means that individuals have 'successfully' segmented or integrated 'life' and work so as to achieve a 
satisfying quality of life, overall satisfaction and less strain or stress around juggling conflicting role demands. Put differently, work-life balance denotes fulfilment of multiple roles while maintaining a positive quality of life." (Blyton et al. (2006). In another definition it's "A perceptual phenomenon characterized by a sense of having achieved a satisfactory resolution of the multiple demands of work and family domains." Higgins, Duxbury \& Johnson (2000). Several theories have been propounded to explain the work-life linkage. These include Segmentation, Compensation, Spillover, Border theory and Role theory.

\section{Segmentation TheORY}

The first perspective of the association in the middle of work and home was that they are divided and self-ruling and don't influence one another. Blood \& Wolfe (1960), who were plots of this perspective, connected this idea to manual labourers. They cleared up that for representatives in disappointing or un-including occupations, detachment of work and home is a characteristic procedure. The single circles game plan viewed the family as a residential shelter for ladies and act as an open stadium for men (Zedeck, 1992).However, this perspective of division was tested via specialists who exhibited that work and family are nearly related spaces of human life (Burke \&Greenglass, 1987; Voydanoff, 1987).

\section{The COMPenSATion TheORY}

This suggested that workers attempt to make up for the absence of fulfillment in one space (work or home) by attempting to discover more fulfillment in the other (Lambert, 1990). Piotrkowski(1979) additionally reasoned that men "look to their homes as sanctuaries, look to their families as wellsprings of fulfillment ailing in the word related circle". Two manifestations of remuneration have been recognized in the writing (Edwards \&Rothbard, 2000). In the first place, an individual may diminish contribution in the disappointing space and expand inclusion in a possibly fulfilling area (Lambert, 1990). Second, the individual may react to disappointment in one area by seeking after prizes in the other space (encounters that may satisfy the individual's goals, (Champoux, 1978). The recent type of remuneration can be either supplemental or receptive in nature (Zedeck, 1992). Supplemental pay happens when people move their interests for remunerating encounters from the disappointing part to a possibly all the more fulfilling one. For instance, people with little selfgovernance at work look for more self-rule outside of their work part. While, reactive compensation represents individuals' efforts to redress negative experiences in one role by pursuing contrasting experiences in the other role such as engaging in leisure activities after a fatiguing day at work.

\section{SPILlOVER TheORY}

The most mainstream perspective of relationship in the middle of work and life was advanced by this theory. A few analysts recommended that workers convey the feelings, attitude, abilities and practices that they secure at work into their family life (Belsky et al., 1985; Kelly \&Voydanoff, 1985; Piotrkowski, 1979; Piotrkowski\&Crits-Christoph, 1981) and the other way around (Belsky et al., 1985; Crouter, 1984). Spillover can be certain or negative. Positive overflow derives that satisfaction and achievement in one area may bring along fulfillment and accomplishment in an alternate space. Negative overflow deduces that issues and despondency in one area may bring along the same feeling in an alternate space (Xu, 2009).

\section{BORDER THEORY}

Clark (2000) exhibited a work/family border hypothesis - another theory about work-life equalization/balance. As indicated by this hypothesis, each of individual's part happens inside a particular space of life, and these spaces are divided by borders that may be physical, transient, or mental. The hypothesis addresses the issue of "crossing borders" between spaces of life, particularly the areas of home and work. As per this theory, the adaptability and porousness of the limits between individuals' work and family lives will influence the level of combination, the simplicity of moves, and the level of contention between these areas. Limits that are adaptable and porous encourage mix in the middle of work and home spaces. At the point when spaces are generally coordinated, move is simpler; however work family clash is more probable. Alternately, when these areas are portioned, move is more effortful, however work family clash is more outlandish (Bellavia\&Frone, 2005) It helps them to accommodate the contending cases of work and home by addressing their own needs and those of their managers. In spite of the fact that definitions and clarifications change, work-life parity is by and large connected with balance, or keeping up a general feeling of agreement in life (Clarke et al., 2004). 


\section{ROLE THEORY}

Work family examination has long been guided by the role stress theory, wherein the negative side of the work family communication has been put under the spotlight. As of late, the accentuation has moved towards the examination of the positive connection in the middle of work and family parts and parts outside work and family lives, and researchers have begun to consider on the quintessence of work life equalization (Jones et al., 2006). It ought to be noticed that the term work life is utilized all through this part from here on as it is more far reaching than the term work family. Nonetheless, when the work of different researchers is alluded to, the terms work life and work family are utilized by references. It is by and large concurred that work life balance is imperative for an individual's mental well-being, and that high self-esteem, fulfillment, and general feeling of amicability in life can be viewed as pointers of an effective harmony in the middle of work and family parts (Clark, 2000; Clarke et al., 2004; Marks \&MacDermid, 1996). Notwithstanding, there is an absence of accord on how work life offset ought to be characterized, measured, and inquired about, and accordingly, the speculating of what constitutes work life balance, how it develops, and what components empower or block it, is still in progress (Grzywacz\& Carlson, 2007; Jones et al., 2006; Voydanoff, 2005). Greenhaus et al (2003) have additionally scrutinized the self-evident presumption that work family balance dependably prompts great results according to them this is an experimental inquiry which has not yet been immovably replied because of different meanings of work- family balance. The starting points of exploration on work life offset can be followed back to investigations of ladies having various parts. Barnett \& Baruch (1985) researched the mental misery (psychological distress) associated with the balance of prizes and concerns created by individual ladies' numerous parts as paid laborer, wife and mother. In view of their examination, Barnett and Baruch characterized role balance as "rewards minus concerns" difference score which could range from positive to negative values. Tiedje and her associates (1990) approached the same examination question from the viewpoint of a typology of part discernment. They contended that ladies may see their work and family parts in various, subjectively distinctive ways, and therefore they built their typology with respect to both the part clash and improvement speculation. As per the contention speculation, different parts with endless requests are prone to cause part strain and conflict for people in light of the fact that the assets they need to meet these requests are limited and rare (Goode, 1960). The center explanation of the upgrade speculation, thus, is that multiple roles give advantages as benefits, status security, mental vitality and self-improvement which grow individual assets and encourage role execution (Marks, 1977;Sieber, 1974). All the more particularly, Tiedje and associates (1990) respected role conflict and role enchantment as autonomous measurements, and hence they contended that it is conceivable to experience simultaneously (a) high conflict and low improvement, (b) high improvement and low conflict, (c) low conflict and low improvement, or (d) high conflict and high improvement. They found that paying little heed to the level of improvement, ladies who experienced high role clash were more discouraged and less fulfilled as folks than ladies having a place with the low conflict high enchantment bunch. On the premise of studies by Barnett and Baruch (1985) and Tiedje and partners (1990), it might be reasoned that high compensates and upgrade joined with low concerns and clash experienced over the parts throughout one's life is gainful for a singular's well-being, and thus these encounters portray role balance. However, Marks \&MacDermid (1996) conceptualize balance pretty contrarily. Conferring to them, role balance is not a result but rather "both a behavioral pattern of acting across roles in a certain way and a corresponding cognitive-affective pattern of organizing one's inner life of multiple selves" (Marks and MacDermid, 1996,). In particular, as per Marks and MacDermid (1996) there are two approaches to draw in different roles; as either positive or negative role balance. Positive part adjust, in Marks and McDermid's hypothesis (cf. Barnett \& Baruch, 1985), alludes to the propensity to take part in every part with just as high exertion, commitment, consideration and consideration, though negative part adjust alludes to the inclination to participate in parts with unresponsiveness, criticism, low exertion and low mindfulness. Because of these behavioural and cognitive-affective propensities, it is hypothesized that positive part adjust will prompt role ease and that negative part adjust will prompt role strain (Marks \&MacDermid, 1996) role straightforwardness and strain comparing with role improvement and conflict, respectively. On account of positive role balance, role conflict is either averted or tackled before intense issues of part administration get to be chronic; This is accomplished by tending to the requests of every part on time, with exertion and consideration. Example, maintaining a strategic distance from unnecessary breaks, calls and e-mails while working, organizing occupation obligations, and upgrading one's expert aptitudes, might considerably encourage overseeing employment obligations all the more 
effectively so that the representative's work time does not cut into his or her assigned family time. Conversely, for people of whom an antagonistic role balance is normal, periodic occurrences of role conflict are liable to amass because of their aloofness towards role related undertakings and obligations, making an ongoing condition of unfulfilled requests. For instance, overlooking one's companion's passionate concerns and staying away from private life obligations, for example, dealing with one's kids or family unit tasks might, over the long run, grow into steady and every day contradictions, which can likewise adversely influence work execution because of the considerable declining of mind-set and concentration.

\section{OVERAll APPRAisal AND COMPONENTS APPROACH}

More recent perspectives about work life offset can be ordered into the general evaluation approach to work life balance, and the segments way to work life equalization (Grzywacz\& Carlson, 2007). General evaluation alludes to an individual's general appraisal concerning the whole of his or her life circumstance. Case in point, work family balance has been characterized as "satisfaction and good functioning at work and home, with a minimum of role conflict" (Clark, 2000), "equilibrium or maintaining overall sense of harmony in life" (Clarke et al., 2004), and "global assessment that work and family resources are sufficient to meet work and family demands such that participation is effective in both domains" (Voydanoff, 2005). At the point when a general evaluation methodology is connected, work-life balance is ordinarily evaluated with general questions (e.g., "All in all, how successful do you feel in balancing your work and personal/family life?" Clarke et al. 2004). A segments way to work life parity stresses balance as a direct developmental inactive build (Edwards \&Bagozzi, 2000), which implies that work family balance comprises of various aspects that go before offset and offer intending to it (Grzywacz\& Carlson, 2007). Case in point, as indicated by Greenhaus et al. (2003), work family balance comprises of time balance, contribution balance, and fulfillment equalization. As indicated by Frone (2003), thus, work family balance comprises of work family clash and work family help (comparing role conflict and enhancement, separately). The preference of the components approach over the 28 general evaluations way to work life equalization is that one can utilize adroitly based measures of balance that take advantage of the distinctive parts of work life balance. These viewpoints structure the general assessment of how well an individual is meeting role -related obligations (Grzywacz\& Carlson, 2007). Taking after the hypothesis of role balance (Marks \&MacDermid, 1996), Greenhaus et al. (2003) have characterized work family balance as "the extent to which an individual is equally engaged in and equally satisfied with - his or her work and family role".Moreover, as indicated by these researchers, work-family adjust comprises of three measurements of which time offset alludes to equivalent time dedicated, involvement balance alludes to equivalent mental exertion and vicinity contributed, and fulfillment balance alludes to equivalent fulfillment communicated crosswise over work and family parts. Greenhaus et al. (2003) see workfamily balance as a continuum where instability for the work roles lies toward one side, and unevenness for the family part lies at the flip side, and balance lies in the centerfavoring neither work nor family part. In the above conceptualization, work-life equalization and unevenness are not seen as intrinsically valuable or negative, separately, for psychological well-being and personal satisfaction. Rather, Greenhaus et al. (2003) state that it ought to be exactly tried whether equivalent time, contribution, and fulfillment balance is preferred for a single person over irregularity for either the work or family role. In their study, it worked out that among people with an abnormal state of engagement across roles, those reporting the most astounding personal satisfaction were the individuals who put more in the family than the work part, that is, they demonstrated an imbalance in favour of family. Concerning their level of engagement, the equally balance people scored lower in personal satisfaction than those favoring family over work, however higher than those favoring work over family. In this way, the individuals who put most in work had the least personal satisfaction. Frone (2003), thusly, has introduced a four-fold scientific classification of work family balance, in which work family balance is characterized as "low levels of inter-role conflict and large amounts of inter-role help". The four-fold scientific categorization is in light of the thought of bi-directionality in the middle of work and family spaces, implying that support in the work part may meddle with or upgrade the execution in the family part, and in like manner, interest in the family part may meddle or improve execution in the work part (Frone et al., 1992;Greenhaus\&Beutell, 1985;Grzywacz\& Marks, 2000; Kirchmey, 1992). In like manner, work-life balance (low clash, high assistance/improvement) is estimated to happen in two headings: from work to non-work spaces and the other way around. Hence, as per Frone (2003), the measurable four parts of work-life balance are work-to-family/non- 
work conflict, family/non-work-to-work conflict, work-to-family/ non-work improvement, and family/non-work-to-work improvement.

\section{Conceptual Models}

Various theoretical models of work life balance/work family conflict/work family improvement have been proposed (Greenhaus\&Beutell, 1985;Frone et al., 1992(b); Guest, 2002; Crooker et al., 2002;Kirrane\& Buckley, 2004;Voydanoff, 2005;Greenhaus\& Powell, 2006; Kelley \& Moen, 2007). Greenhaus\&Beutell (1985) gave a model of the wellsprings of work family conflict. Frone et al. (1992) inspected the forerunners and results of work family clash and surveyed on the off chance that it plays an imperative capacity in work and family push research. A complete model of work-family interface was created and tried. The direct indicators proposed in the model were occupation stressors (work weight, absence of self-sufficiency, part uncertainty), family stressors (parental workload, degree of youngsters rowdiness, absence of mate bolster, level of strain in relationship), work contribution and family association. The outcomes showed a positive complementary relationship between W-F clash (work to family clash) and F-W clash (family to work clash). Work stressors and occupation association were discovered to be absolutely identified with the recurrence of W-F clash. Then again, family stressors and family association were decidedly identified with the recurrence of F-W clash. Both sorts of work family clash were decidedly identified with a particular measure of inside area trouble. F-W clash was decidedly identified with work trouble, though W-F clash was emphatically identified with family trouble, at any rate among hands on labourers. Visitor (2002) gave a model delineating the reasons, nature and outcomes of a work-life parity referring to late research to represent the different measurements. As per the model, the determinants of work life parity are placed in the work and home connections. Context oriented determinants incorporate requests of work, society of work, requests of home and society of home. Singular determinants incorporate work introduction (i.e. the degree to which work (or home) is a focal life interest), identity, vitality, individual control and adapting, sexual orientation and age, life and profession stage. The way of work life offset was characterized both equitably and subjectively. The target markers incorporate hours of work and hours of uncommitted or extra time outside work. Subjective pointers allude to the conditions of equalization and unevenness. As indicated by Visitor, equalization may be accounted for when equivalent weight is offered both to work and home or, when home or work rules by decision. Overflow happens when there is obstruction of one circle of existence with other. The model further shows various results of work life parity which incorporate individual fulfillment and wellbeing at work, the home, execution at work and home, effect on others at work, family and friends.

\section{DISCUSSION OF FINDINGS}

Greenhaus\&Beutell (1985) in light of the work of Kahn et al. (1964), characterized work family conflict as: "A type of inter-role conflict in which the part weights from work and family spaces are commonly in-congruent in some respect. That is, interest in the work (family) part is made harder by virtue of investment in the family (work) part." Clark likewise saw it as work-family balance, and characterized it as the degree to which people are just as occupied with and similarly fulfilled by work and family parts. Gropel (2005) alluded to Work-family balance as the extent to which an individual has the capacity to simultaneously balance the demands of both paid work and family obligations, though work-family conflict spoke to incompatibilities in the middle of work and family obligations as a result of constrained assets like time and energy

Greenblatt (2002) defined work-life balance as the absence of unacceptable levels of conflict between work and non-work demands. Greenhaus et al (2003) saw work-life balance as a matter of degree, a continuum anchored at one end by extensive imbalance in favour of a particular role like family through some relatively balanced state to extensive imbalance in favour of the other role (work).

The findings of past studies and conceptual clarifications as deduced from literature were reported.

- Work-life balance can be explained by some theories such as the segmentation theory, which says that work and home or life are totally segmented and independent of each other.

- The compensation theory suggested that workers attempt to reward for the absence of fulfillment in one zone (work or life) by attempting to get more fulfillment in the other.

- The most popular view on work-life balance is the spill-over theory, this means when workers carry emotions, attitudes, behaviors (positive or negative) established in one domain to the other. 
- Positive spill-over refers to the fact that satisfaction and happiness in one domain could lead to satisfaction in another.

- Negative spill-over deduces that difficulties and frustration in one domain could lead to the same emotion in the other domain.

- The border theory infers that each role takes place within a domain and each domain is separated by physical, temporal, or psychological borders. The theory addresses the issue of "crossing borders" between domains of life, especially the domains of life and work.

- Starting points of exploration on work-life balance can be moved back to investigations of ladies having several roles. Barnett \& Baruch (1985) explored the mental misery joined with the balance of prizes/rewards and concerns produced by individual women's numerous roles as paid laborer, wife and mother. They found that positive role quality - a greater number of prizes than concerns experienced in a given part was identified with low levels of role over-burden, part clash and anxiety

- Recent views about work-life balance can be classified into the overall appraisal approach to worklife balance, and the components approach to work-life balance (Grzywacz\& Carlson, 2007).

Overall appraisal refers to an individual's general assessment concerning the entirety of his or her life situation. For example, work-life balance has been defined as "satisfaction and good functioning at work and home, with a minimum of role conflict" (Clark, 2000).

- Finally it was observed that a balance between the work and life of an employee is both the responsibility of the organization and the employee in order for the employee to concentrate and be happy with his job which will ensure an increase in his/her performance.

\section{RECOMMENDATIONS}

From the theoretical findings and empirical findings above, the research objectives of embarking on this research has been achieved and then the following recommendations are made based on the findings of this study:

- Organizations should implement more family friendly policies, this will provide greater flexibility to all employees, including supervisors, managers and other senior staff, and will ensure flexible working hours schedules, rosters and leave arrangements to accommodate their family and personal responsibilities, without detriment or penalty.

- Pre-exit interviews that include questions such as whether difficulties in balancing work and family/personal responsibilities were a contributing factor to the employee leaving, to be conducted prior to the employee leaving.

- Organizations should take work-life balance of their employees utterly seriously by developing of new policies and initiatives.

- Knowledge should be improved on work-life balance, increase cognizance of employees' rights to access flexible working arrangements, and what assistance and services are available to them directly or by recommendation.

\section{ConClusion}

Work-life balance is increasing in importance due to its benefits and its added advantage to employee and organization performance. Organizations should make more efforts to implement work-life friendly policies and create a working environment that suits its employee's welfare and lifestyle to ensure work-life balance, this is important as employees with balanced life's yield best results. Therefore work-life balances have become necessary in organizations which consider success as an option. Based on the findings of the study, it can be concluded that work-life balance holds a lot of benefits for organizations. It is a platform for improving employees' performance and for eventual achievement of organizational goals. If one has managed to apportion the essential time for every facet of life duly and not reflect the problems in one part of life, it means that he has been able to achieve work-family balance (Aycan et al., 2007). 


\section{REFERENCES}

Alain De Botton, T. (2001). Working part-time. Achieving a successful work-life balance? The British journal of psycology, vol.55, 99-122

Aluko, Y. (2009). Work-Family Conflict And Coping Strategies Adopted By Women In Academia. Gen \&Behav.

.Asika, N. (1991). Research Methodology in Behavioural Sciences. Longman Nigeria Plc.

Aycan, Z., Eskin, M., \&Yavuz, S. (2007). Life balance. Istanbul: System Press.

Barnett, R., \& Baruch, G. (1985). Women's involvement in multiple roles and psychological distress. J PersSoc Psychology, Vol.49, 135-145.

Belsky, J., Perry-Jenkins, M., \&Crouter, A. (1985). The work-family interface and marital change across the transition of parenthood. Journal of family issues, vol.6, 205-220.

Blood, R., \& Wolfe, D. (1960). Husbands and Wives. New York: MacMillan.

Blyton, P., \& Bacon, N. (2006). The effects of co-operating or conflicting over work restructuring: evidence from employees. The Sociological Review, 54(1), 1-19.

Burke, R., \& Greenglass, E. (1987). Work and family. In C.L.Cooper \& I.T.Robertson (Eds). New York: Wiley.

Cannon, M. (1998). Work and family in the United States .A critical Review and Agenda for research and policy, vol.5, 2.

Carlson, D., Kacmar, K., Wayne, J., \& Grzywacz, J. (2006). Measuring the positive side of the workfamily interface. Development and validation of a work-family enrichment scale. Journal of vocational behaviour, Vol.68, 131-164.

Cegarra-Leiva, D., Sánchez-Vidal, M., \& Gabriel Cegarra-Navarro, J. (2012). Understanding the link between work life balance practices and organisational outcomes in SMEs. Personnel Review, 41(3), 359-379.

Champoux, J. (1978). Perceptions of work and non-work. A reexamination of the compensatory and spillover models. Sociology of work and occupation, Vol.5, 402-422.

Clark, S. (2000). Work/family border theory. A new theory of work/family balance, Vol.53, 747-770.

Clarke, M., Koch, L., \& Hill, E. (2004). The work-family interface. Differentiating balance and fit.Family and consumer sciences research journal, vol.33, 121-140.

Crooker, K. J., Smith, F. L., \& Tabak, F. (2002). Creating work-life balance. A model of pluralism across life domains. Human resource development review, vol.1, 387-419.

Crouter, A. (1984). Spillover from family to work. The neglected side of the work-family interface.Human Relations, vol.37, 425-442.

Deery, M. (2008). Talent management, work-life balance and retention strategies. Int J Contemp Hospitality Mngt, 20(7), 792-806.

Edwards, J. \& Bagozzi, L. (2000). The 2004 Don Wood Lecture in industrial relations. Retrieved January 4, 2007, from irc.queensu.ca: http://irc.queensu.ca/gallery/1/dwls-linda-duxburyonwork-life-conflict.pdf

Edwards, J., \& Rothbard, N. (2000). Mechanisms linking work and family. Clarifying the relationship between work and family constructs.Academy of management Review., vol.25,Pg 178-199.

Frone, M. (2003). The effects of work-family conflict on work stress, job satisfaction and organizational devotion. Adana, Turkey.

Frone, M.; Emslie, C., \& Hunt, K. (1992a). 'Live to Work' or 'Work to Live'? A Qualitative Study of Gender and Work-life Balance among Men and Women in Mid-life. Gender, Work \& Organization, 16(1), 151-172.

Frone, et al, (1992b). Work/Personal Life Balance: A Construct Development Study. USA: Bowling green state university.

Frone, M., Russell, M., \& Cooper, M. (1997). Relation of work-family conflict to health outcomes: A four-year longitudinal study of employed parents. Journal Of Occupational And Organizational Psychology, 70(4), 325-335.

Goode, W. (1960). A theory of role strain. Am Sociol Rev, vol.25,Pg 483-496. 
Grady, G., \& McCarthy, A. (2008). Work-life integration: experiences of mid-career professional working mothers. Journal Of Managerial Psych, 23(5), 599-622.

Greenblatt, E. (2002). Work/life balance. Wisdom or whining.Organizational Dynamics, vol.31,Pg 177-194.

Greenhaus, J., \& Beutell, N. (1985). Sources of conflict between work and family roles. Academy of Management Review, vol.10,Pg 76-88.

Greenhaus, J., \& Parasuraman, S. (1999). Research on work, family, and gender. Current status and future directions in G. N. Powell(Ed), Handbook of gender and work., vol.20,Pg 391-412.

Greenhaus, J., \& Powell, G. (2006). When work and family are allies. A theory of work-family enrichment. Academy of management review, vol.31,Pg 72-92.

Greenhaus, J., Collins, K., \& Shaw, J. (2003). The relation between work-family balance and quality of life. Journal of vocational behaviour, vol.63,Pg 510-531.

Gropel, P. (2005). On the Theory of Life Balance. Germany: University of osnabruck.

Grzywacz, J. (2000). Toward a theory of work-family enrichment. Houston, TX.

Grzywacz, J., \& Marks, N. (2000). Reconceptualizing the work-family interface. An ecological perspective on the correlates of positive and negative spillover between work and family.Journal of occupational Health psycology., vol.5,Pg 111-126.

Grzywacz, J., Carlson, D., Kacmar, K. M., \& Wayne, J. (. (2007). A multi-level perspective on the synergies between work and family. Journal of occupational and organizational psycology, vol.80, 559-574.

Grzywacz, J., Carlson, D., Kacmar, K. M., \& Wayne, J. (2007). A multi-level perspective on the synergies between work and family. Journal of occupational and organizational psychology, vol.80, 559-574.

Guest, D. (2002). Perspectives on the study of work-life balance. Social Science information, vol.41,Pg 255-279.

Heather, S. (2011). Examining the relationship between work-life conflict and life satisfaction in executives. The role of problem focused techniques, vol.8, 4.

Higgins, C., Duxbury, L., \& Irving, R. (1992). Work-family conflict in the dual career family. Organizational behaviour and human decision processes, vol.51, 51-75.

Hammer, et al. P. (2005). Associations and Their Journals: The Search for an "Official" Voice. Sociological Perspectives, 48(2), 271-289.

Jones, F., Burke, R., \& Westman, M. (2006). Work-life balance: a psychological perspective. New York,NY: Psychology press.

Kahn, R., Wolfe, D., Quinn, R., Snoek, J., \& Rosenthal, R. (1964). Organizational stress:Studies in role conflict and ambiguity. New York: Wiley.

Kelly, S., \& Moen, R., (2007). Reflections on the integration of paid work and the rest of life. Journal of managerial psychology, vol.18, 824-841.

Kelly, R., \& Voydanoff, P. (1985). Work/family role strain among employed parents. Family Relations, vol.32, 367-374.

Kirchmey, S. (1992). Work-life integration. Chichester: Wiley.

Kirrane, M., \& Buckley, F. (2004). Contributing to work family domain conflict . Retrieved March 14, 2009, from www.link.dcu.ie:www.link.dcu.ie/publications/workingpaperseries

Lambert, S. (1990). Processes linking work and family. A critical review and research agenda.Human relations, vol.43,Pg 239-257.

Marks, S. (1977). Multiple roles and role strain: Some notes on human energy, time and commitment. Am sociol rev, vol.42, 921-936.

Marks, S., \& MacDermid, S. (1996). Multiple roles and the self. A theory of role balance. J Marriage Fam, vol.58, 417-432.

Muse, et al. . (2008). Work-Family Spillover Among Dual-Earner Couples. Advances In Life Course Research, 12, 361-382.

Piotrkowski, C., \& Crits-Christoph, P. (1981). Women's job and family adjustment. Journal of family issues, vol.32,Pg 126-147. 
Piotrkowski, S. (1997). Work-life balance. Organizational strategies for sustainable growth.HRM review., vol.12, 33-37.

Sieber, S. (1974). Toward a theory of role accumulation. Am SociolRev, vol.39, 567-578.

Tiedje, L., Wortman, C., Downey, G., Emmons, C., Biernat, M., \& Lang, E. (1990). Women with multiple roles. Role-compatibility perceptions, satisfaction, and mental health. J Marriage Fam, vol.52, 63-72.

Visitor, N. (2002). Work/Life Balance. Challenges and Solutions, Society for Human resource management, vol.2, 1-10.

Voydanoff, P. (1987). Work and Family Life. . Newbury Park, CA: Sage.

Voydanoff, P. (2005). Consequences of Boundary-Spanning Demands and Resources for Work-toFamily Conflict and Perceived Stress. Journal Of Occupational Health Psychology, 10(4), 491503.

Wayne, et al. L. (2004). Working Time and Work-Family Balance: A Review of Employees' Preferences. Asia Pacific Journal Of Human Resources, 42(2), 166-184.

$\mathrm{Xu}, \mathrm{L}$. (2009). View on Work-family linkage and work-family conflict model. International journal of business and management, vol.4,Pg 229-233.

Zedeck, S. (1992). Work, Families, and Organizations. San Francisco: Jossey-Bass.

\section{AUTHORS' BIOGRAPHY}

AKINYELE, Samuel Taiwo, lectures at Federal University of Agriculture Abeokuta, Ogun State, Nigeria, Dept.of Entrepreneurial Studies, College of Management Sciences. He has published several papers both locally and international and have been cited severally too around the world by other scholars.

PETERS, MC, was a graduate of Covenant University, Dept of Business Management.

AKINYELE, FE, was a postgraduate student in Crawford University, Ogun State, Nigeria. 